\title{
Toxicity and pathological effects of orally administered ivermectin in Atlantic, chinook, and coho salmon and steelhead trout
}

\author{
S. C. Johnson ${ }^{1,2}$, M. L. Kent ${ }^{1}$, D. J. Whitaker $^{1}$, L. Margolis ${ }^{1}$ \\ ${ }^{1}$ Department of Fisheries and Oceans, Biological Sciences Branch, Pacific Biological Station, Nanaimo, British Columbia, \\ Canada V9R $5 \mathrm{~K} 6$ \\ ${ }^{2}$ Department of Zoology, University of British Columbia, Vancouver, British Columbia, Canada V6T 2A9
}

\begin{abstract}
Because ivermectin $\left(22,23\right.$-Dihydroavermectin $\left.B_{1}\right)$ has been proposed as an oral treatment against sea lice infections of farmed salmonids, we investigated the toxicity and pathological effects of various doses of ivermectin administered orally every second day to steelhead trout Oncorhynchus mykiss, coho salmon Oncorhynchus kisutch, chinook salmon Oncorhynchus tshawytscha and Atlantic salmon Salmo salar under laboratory conditions. These species differed in their ability to tolerate ivermectin, with coho salmon the most tolerant followed by chinook, then Atlantic salmon. Unequivoca] results for steelhead trout were not obtained due to a secondary disease outbreak (vibriosis). Histological examination of the major organ systems revealed no pathological changes that could be associated with ivermectin toxicity in any of the salmon specins tested.
\end{abstract}

KEY WORDS: Ivermectin - Oncorhynchus kisutch. Oncorhynchus mykiss . Oncorhynchus tshawytscha Parasite control Parasite treatment Pathological effects. Salmo salar. Sea lice Sub-lethal effects Toxicity

\section{INTRODUCTION}

Several species of marine ectoparasitic copepods including Caligus clemensi, Caligus elongatus, Caligus teres, and Lepeophtheirus salmonis commonly infect and can cause serious disease in sea-farmed salmonids (Brandal \& Egidius 1979, Kabata 1979, 1988, Wootten et al. 1982, Reyes \& Bravo 1983, Hogans \& Trudeau, 1989a, b, Pike 1989). Epizootics of these sea lice species are most commonly treated by bath treatments of dichlorvos, which is the active ingredient in 'Nuvan $500 \mathrm{EC}$ ' or 'Aquaguard' (Grave et al. 1991a, b, Jackson \& Costello 1992, Roth et al. 1993). These treatments are labor-intensive and can cause high levels of fish mortality due either to toxicity of the dichlorvos itself or to secondary diseases brought on by physical injury and/or stress incurred during the treatment. Furthermore, populations of Lepeophtheirus salmonis, which is the most important species of sea lice with respect to disease, are reported to be developing resistance to dichlorvos (Jones et al. 1992). These problems, as well as concerns about the release of dichlorvos into the marine environment, have necessitated the development of alternative treatment methods for sea lice.

Ivermectin (22,23-Dihydroavermectin $\left.\mathrm{B}_{1}\right)$ is a broadspectrum antiparasitic drug which is effective in controlling nematodes and parasitic arthropods in a wide variety of host species when administered orally (Campbell 1989). Currently, ivermectin is used to control sea lice at some sea farm sites in Ireland and possibly Scotland (Roth et al. 1993). In preliminary studies, a single orally administered dose of ivermectin $\left(0.20 \mathrm{mg}\right.$ ivermectin $\mathrm{kg}^{-1}$ of fish weight) was determined to be effective in reducing adult sea lice numbers on Atlantic salmon Salmo salar without any treatment-associated mortality (Palmer et al. 1987). Single higher doses of $0.4 \mathrm{mg} \mathrm{kg}^{-1}$ (fed to both Atlantic salmon, and rainbow trout Oncorhynchus mykiss) and $1.0 \mathrm{mg} \mathrm{kg}^{-1}$ (fed only to rainbow trout) resulted in significant mortalities (Palmer et al. 1987). Ivermectin given as a single oral dose of $0.20 \mathrm{mg} \mathrm{kg}^{-1}$ or as 2 doses of $0.05 \mathrm{mg} \mathrm{kg}^{-1}$ given over $1 \mathrm{wk}$, gave a marked reduction in the number of Ergasilus labracis on Atlantic salmon parr (O'Halloran et al. 1992). A single dose of 0.20 
$\mathrm{mg} \mathrm{kg}^{-1}$ resulted in a slight rise in the mortality rate, whereas the two $0.05 \mathrm{mg} \mathrm{kg}^{-1}$ doses had no effect on the mortality rate. Smith et al. (1993) reported that treatments of $0.2 \mathrm{mg} \mathrm{kg}^{-1}$ every $2 \mathrm{wk}, 0.075 \mathrm{mg} \mathrm{kg}^{-1}$ twice a week, $0.1 \mathrm{mg} \mathrm{kg}^{-1}$ once a week, and $0.05 \mathrm{mg}$ $\mathrm{kg}^{-1}$ twice a week have no effect on morbidity or mortality of Atlantic salmon.

These aforementioned studies have provided guidelines to the toxicity of ivermectin in Atlantic salmon. However, the toxicity of this drug to other salmonids was not determined, except in the study of Palmer et al. (1987) in which rainbow trout fed 1 dose at $1.0 \mathrm{mg}$ $\mathrm{kg}^{-1}$ fish experienced high mortality. Before the efficacy of ivermectin for the control of sea lice on Atlantic and other species of salmon can be determined, additional information on its toxicity and possible side effects needs to be obtained. The aim of this study was to determine the toxicity of orally administered ivermectin to steelhead trout salmon Oncorhynchus mykiss, Atlantic salmon Salmo salar, coho salmon Oncorhynchus kisutch and chinook salmon Oncorhynchus tshawytscha. The effects of ivermectin on fish behaviour, and the gross morphology and histopathology of the major organ systems, were also determined.

\section{MATERIALS AND METHODS}

Preparation of treated feeds. Ivermectin used in our experiment was in the form of a veterinary preparation. of $1 \% \mathrm{w} / \mathrm{v}$ oral drench (Eqvalan; Merck Frosst Canada). Ivermectin carrier solution was made in our laboratory following the formulation given in the Eqvalan product information sheet. Commercial salmon pellets (White Crest) were allowed to dry for $24 \mathrm{~h}$ at room temperature and sprayed with either solutions of Eqvalan or the carrier solution diluted to the targeted dosage level with distilled deionized water. Diets were stored frozen at $20^{\circ} \mathrm{C}$ in sealed containers.

Feed analysis. Levels of ivermectin in both the control and treated diets were confirmed by the Health of Animals Laboratory, Agriculture Canada, Saskatoon, following the methods given in Doherty et al. (1990). Assayed levels in the treated feeds were generally considerably lower than the targeted levels sprayed (Table 1). The doses referred to throughout the remainder of this paper are the targeted doses.

Dosage levels and feeding rates. Atlantic salmon with an average weight of approximately $800 \mathrm{~g}$ were fed 5 levels of ivermectin $(0.05,0.10,0.20,0.50$, and $1.0 \mathrm{mg} \mathrm{kg} \mathrm{kg}^{-1}$ fish) and carrier compound equivalent to that received in the $1.0 \mathrm{mg} \mathrm{kg}^{-1}$ fish dose. Coho salmon with an average weight of approximately $50 \mathrm{~g}$ were fed 3 levels of ivermectin $\left(0.05,0.10\right.$, and $0.20 \mathrm{mg} \mathrm{kg}^{-1}$ fish). Chinook salmon with an average weight of
Table 1 Results of feed analysis for treatments of Atlantic, chinook, and coho salmon and steelhead trout. Values were corrected for an average recovery of $87.7 \%$ and are based on duplicate analyses. nd: none detected

\begin{tabular}{|lcc|}
\hline Feed sample & $\begin{array}{c}\text { Sprayed } \\
\text { ivermectin } \\
\text { (mg kg } \\
\text { feed) }\end{array}$ & $\begin{array}{c}\text { Recovered } \\
\text { ivermectin } \\
\text { (mg kg } \\
\text { feed) }\end{array}$ \\
\hline Untreated feed & 0 & nd \\
Atlantic carrier solution & 0 & nd \\
Atlantic $0.05 \mathrm{mg} \mathrm{kg}^{-1}$ group & 10.0 & 6.7 \\
Atlantic $0.10 \mathrm{mg} \mathrm{kg}^{-1}$ group & 20.0 & 11.3 \\
Atlantic $0.20 \mathrm{mg} \mathrm{kg}^{-1}$ group & 40.0 & 21.0 \\
Atlantic $0.50 \mathrm{mg} \mathrm{kg}^{-1}$ group & 100.0 & 40.4 \\
Atlantic $1.0 \mathrm{mg} \mathrm{kg}^{-1}$ group & 200.0 & 97.2 \\
Chinook $0.05 \mathrm{mg} \mathrm{kg}^{-1}$ group & 10.1 & 9.1 \\
Chinook $0.10 \mathrm{mg} \mathrm{kg}^{-1}$ group & 19.7 & 13.2 \\
Coho 0.05 $\mathrm{mg} \mathrm{kg}^{-1}$ group & 10.0 & 11.0 \\
Coho $0.10 \mathrm{mg} \mathrm{kg}^{-1}$ group & 20.0 & 14.9 \\
Coho 0.20 $\mathrm{mg} \mathrm{kg}^{-1}$ group & 20.0 & 13.6 \\
Steelhead $0.05 \mathrm{mg} \mathrm{kg}^{-1}$ group & 5.0 & 3.6 \\
Steelhead $0.10 \mathrm{mg} \mathrm{kg}^{-1}$ group & 10.0 & 6.5 \\
\hline
\end{tabular}

approximately $70 \mathrm{~g}$ and steelhead trout with an average weight of approximately $115 \mathrm{~g}$ were fed 2 levels of ivermectin ( 0.05 and $0.10 \mathrm{mg} \mathrm{kg}^{-1}$ fish). Medicated diet was fed every second day for $50 \mathrm{~d}$ or until all the fish stopped feeding. Non-medicated diet was fed every other day and after the termination of the ivermectin feedings. Control fish were fed the untreated diet daily, Except for coho salmon, which were fed at $1.0 \%$ body weight per day, treated diets were fed at a rate of $0.5 \%$ body weight per day.

Sample size and monitoring. Atlantic salmon were maintained in $3500 \mathrm{l}$ tanks and all other species in 5001 tanks, supplied with flowing filtered seawater. The mean and range of the seawater temperatures during the experiments are given in Table 2 . Salinities ranged between 28 and $30 \%$. For each species, 50 fish

Table 2. Mean $\pm \mathrm{SD}$ and range in parentheses of seawater temperatures over the experimental periods

\begin{tabular}{|llc|}
\hline Species & \multicolumn{1}{c}{ Treatments } & Temp. $\left({ }^{\circ} \mathrm{C}\right)$ \\
\hline Atlantic salmon & Controls, $0.20,0.50$ and & $8.7=0.4$ \\
& $1.0 \mathrm{mg} \mathrm{kg}^{-1}$ & $(8.0-9.2)$ \\
Atlantic salmon & Controls, 0.05 and & $9.0 \pm 05$ \\
& $0.10 \mathrm{mg} \mathrm{kg}^{-1}$ & $(8.0-10.5)$ \\
Atlantic salmon & Carrier solution and & $12.5 \pm 0.6$ \\
& Controls & $(11.1-13.7)$ \\
Chinook salmon & Controls and all & $10.3 \pm 0.5$ \\
& treatment levels & $(9.4-13.0)$ \\
Coho salmon & Controls and all & $12.1=0.8$ \\
& treatment levels & $(10.6-14.7)$ \\
Steelhead trout & Controls and all & $110 \pm 0.9$ \\
& treatment levels & $(9.8-13.0)$ \\
& & \\
\hline
\end{tabular}


of a similar size were assigned to each of the ivermectin-treated groups and 25 fish to each of the control groups. A group of 20 Atlantic salmon was fed the diet containing the ivermectin carrier. Twenty-five fish from each of the control and ivermectin-treated groups, and all 20 Atlantic salmon in the ivermectin carrier group, were anesthetized with MS-222 and weighed to determine an average weight $( \pm S D$ ) of fish and the total weight of fish in each tank. The amount of diet fed to the fish in each tank was based upon the initial total weight of fish in the tank.

Fish were fed once a day before they were disturbed by removal of dead or moribund fish. The amount of treated feed eaten was estimated and observations of feeding activity and other behaviours (e.g. lethargy, hyperactivity) were made. The weight, fork length, and presence or absence of food in the stomach were recorded for all sampled fish.

Atlantic salmon treated at levels of $0.2,0.5$, or $1.0 \mathrm{mg}$ $\mathrm{kg}^{-1}$ were monitored for mortality and behaviour over $27 \mathrm{~d}$ after which time the experiments were terminated due to high mortalities. The remaining groups were monitored for $64 \mathrm{~d}$.

Statistical analysis. Mortality rates were compared between ivermectin doses using $G$-tests (Sokal \& Rohlf 1981)

Histology. Samples of liver, spleen, kidney, pyloric caeca, posterior intestine, gill, brain, and eye were taken from the moribund fish throughout the experiment and from 5 apparently healthy fish from each treatment and control group at termination of the experiments. In addition, samples of 5 Atlantic salmon from the $1.0 \mathrm{mg} \mathrm{kg}^{-1}$ treatment group were collected weekly after the cessation of feeding. All tissues were fixed in Davidson's solution, wax-embedded, cut to a thickness of $5 \mu \mathrm{m}$, and stained with hematoxylin and eosin.

\section{RESULTS}

\section{Atlantic salmon}

The cumulative mortality of Atlantic salmon to 5 levels of orally administered ivermectin is given in Fig. 1. There were no mortalities in the control group or in the group fed the ivermectin carrier solution. Cumulative mortalities in the $0.05 \mathrm{mg} \mathrm{kg}^{-1}$ and the $0.10 \mathrm{mg} \mathrm{kg}^{-1}$ treatment groups were 10 and $14 \%$, respectively, at the end of the experiment. Cumulative mortalities were significantly higher $(G$-test; $p<0.05)$ in the 0.20 , 0.50 , and $1.0 \mathrm{mg} \mathrm{kg}^{-1}$ treatment groups when compared to the other treatment levels, with values of 80 , 84 , and $94 \%$, respectively.

Fish in the $0.05 \mathrm{mg} \mathrm{kg}^{-1}$ treatment group showed a

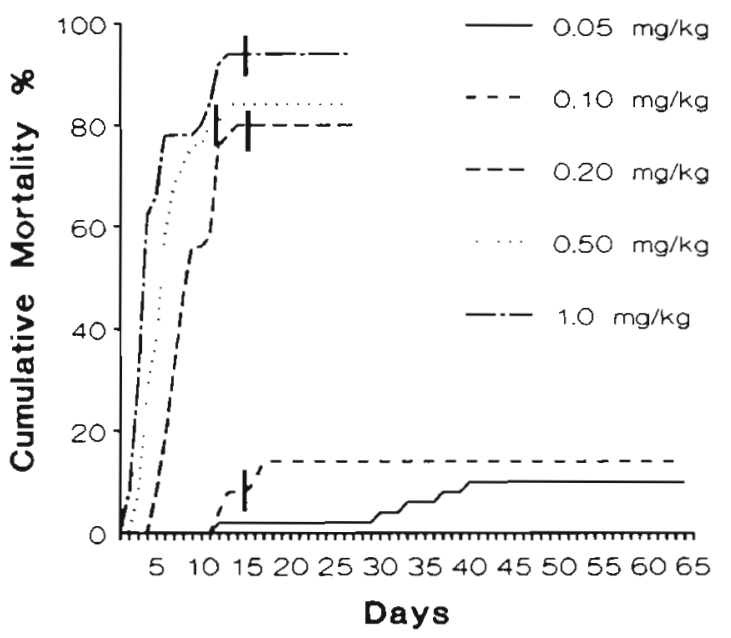

Fig. 1. Salmo salar. Toxicity of orally administered ivermectin to Atlantic salmon. Fish were fed a commercial diet sprayed with ivermectin in the form of a veterinary preparation of $1 \%$ w/v oral drench (Eqvalan; Merck Frosst Canada) at targeted dosages of $0.05,0.10,0.20,0.50$ and $1.0 \mathrm{mg} \mathrm{kg}^{-1}$ fish every second day. For the $0.20,0.50$ and $1.0 \mathrm{mg} \mathrm{kg}^{-1}$ diets the experiment was terminated at Day 27. No mortalities occurred in the control group or in the group fed the carrier solution. Bars indicate the point at which all feeding activity ceased

reduction in their feeding activity, some loss of equilibrium, and a darkened colouration after 6 doses of ivermectin ( $12 \mathrm{~d}$ ). On average $66 \%$ of the daily ration was eaten after this time. Feeding activity ceased after 7 doses of ivermectin (14 d) in the $0.10,0.20$, and $1.0 \mathrm{mg}$ $\mathrm{kg}^{-1}$ treatment groups, and after 6 doses (12 d) in the $0.50 \mathrm{mg} \mathrm{kg}{ }^{-1}$ treatment group. With the exception of an additional $4 \%$ mortality in the $0.50 \mathrm{mg} \mathrm{kg}^{-1}$ treatment group and a $6 \%$ mortality in the $0.10 \mathrm{mg} \mathrm{kg}^{-1}$ treatment group, mortalities ceased after the fish stopped feeding. Fish showed a loss of equilibrium after 1 dose in the 0.50 and $1.0 \mathrm{mg} \mathrm{kg}^{-1}$ treatment groups and after 3 doses in the $0.20 \mathrm{mg} \mathrm{kg}^{-1}$ treatment group. All fish in these groups darkened in colour, and the eyes of the moribund and surviving fish were rolled ventrally so that the lenses were no longer visible. The position of the eyes returned to normal after death.

The $0.10 \mathrm{mg} \mathrm{kg}^{-1}$ treatment group was fed untreated food from Day 19 (5 d after cessation of feeding on treated diet) to the end of the experiment. However, feeding activity of this group was reduced when compared to that of the controls.

\section{Chinook salmon}

There were no mortalities in the chinook control or in the $0.05 \mathrm{mg} \mathrm{kg}^{-1}$ treatment group, and a $10 \%$ cumulative mortality occurred in the $0.10 \mathrm{mg} \mathrm{kg}^{-1}$ treatment 


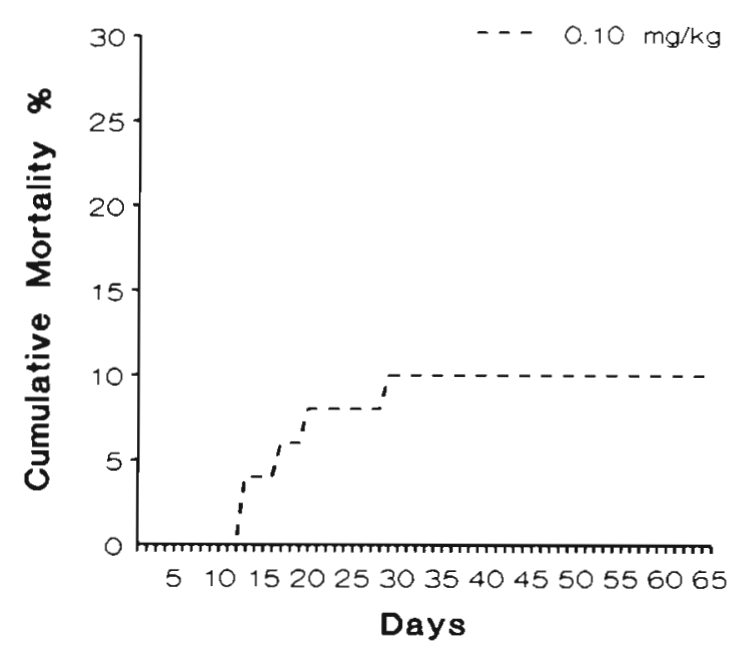

Fig. 2. Oncorhynchus tshawytscha. Toxicity of orally administered ivermectin to chinook salmon. Fish were fed a commercial diet sprayed with ivermectin in the form of a veterinary preparation of $1 \% \mathrm{w} / \mathrm{v}$ oral drench (Eqvalan; Merck Frosst Canada) at targeted dosages of 0.05 and $0.10 \mathrm{mg} \mathrm{kg}^{-1}$ fish every second day. No mortalities occurred in the control group or in the $0.05 \mathrm{mg} \mathrm{kg}^{-1}$ treatment group

group (Fig. 2). Both treatment groups consumed their full treated food ration throughout the experiment. A reduction in the feeding activity was noted after 13 doses in both treatment groups. At the end of the experiment the $0.10 \mathrm{mg} \mathrm{kg}^{-1}$ group was darker in colour and was feeding much more slowly than the $0.05 \mathrm{mg}$ $\mathrm{kg}^{-1}$ treatment group. Down-turned eyes, as seen in the Atlantic salmon that were fed the higher doses, were not observed in chinook salmon.

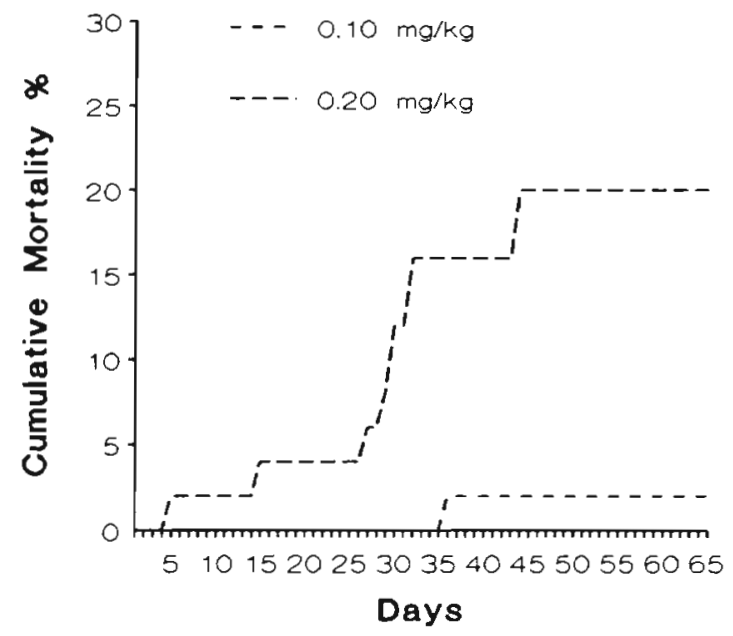

Fig. 3. Oncorhynchus kisutch. Toxıcity of orally administered ivermectin to coho salmon. Fish were fed a commercial diet sprayed with ivermectin in the form of a veterinary preparation of $1 \%$ w/v oral drench (Eqvalan; Merck Frosst Canada) at targeted dosages of $0.05,0.10$, and $0.20 \mathrm{mg} \mathrm{kg}^{-1}$ fish every second day. No mortalities occurred in the $0.05 \mathrm{mg} \mathrm{kg}^{-1}$ treatment group

\section{Coho salmon}

The coho control group had an $8 \%$ cumulative mortality over the experimental period. No mortalities occurred in the $0.05 \mathrm{mg} \mathrm{kg}^{-1}$ treatment group, and only a $2 \%$ cumulative mortality in the $0.10 \mathrm{mg} \mathrm{kg}^{-1}$ treatment group. In the $0.20 \mathrm{mg} \mathrm{kg}^{-1}$ treatment group there was a $20 \%$ cumulative mortality at the end of the experiment (Fig. 3),

Although feeding activity was reduced when compared to the controls, full treated feed rations were eaten in the 0.05 , and $0.10 \mathrm{mg} \mathrm{kg}^{-1}$ treatment groups throughout the experiment. A reduction in the feeding activity of the $0.20 \mathrm{mg} \mathrm{kg}^{-1}$ treatment group was noted after 5 doses of ivermectin (Day 11). On average the $0.20 \mathrm{mg} \mathrm{kg} \mathrm{kg}^{-1}$ treatment group consumed approximately $68 \%$ of their treated food ration after this time. Fish in the 0.05 and $0.10 \mathrm{mg} \mathrm{kg} \mathrm{kg}^{-1}$ groups began to darken after about 16 doses of ivermectin. Those in the $0.20 \mathrm{mg} \mathrm{kg}^{-1}$ group darkened after 2 doses. Downturned eyes, as seen in the Atlantic salmon, were not observed in coho salmon.

\section{Steelhead trout}

There was a $4 \%$ cumulative mortality in the steelhead control group over the experimental period (Fig. 4). Cumulative mortality in the $0.05 \mathrm{mg} \mathrm{kg}^{-1}$ treatment group was $68 \%$ at the end of the experiment. The cumulative mortality in the $0.10 \mathrm{mg} \mathrm{kg}^{-1}$ group was significantly lower $(48 \%)$ ( $G$-test; $\mathrm{p}<0.05$ ) by the

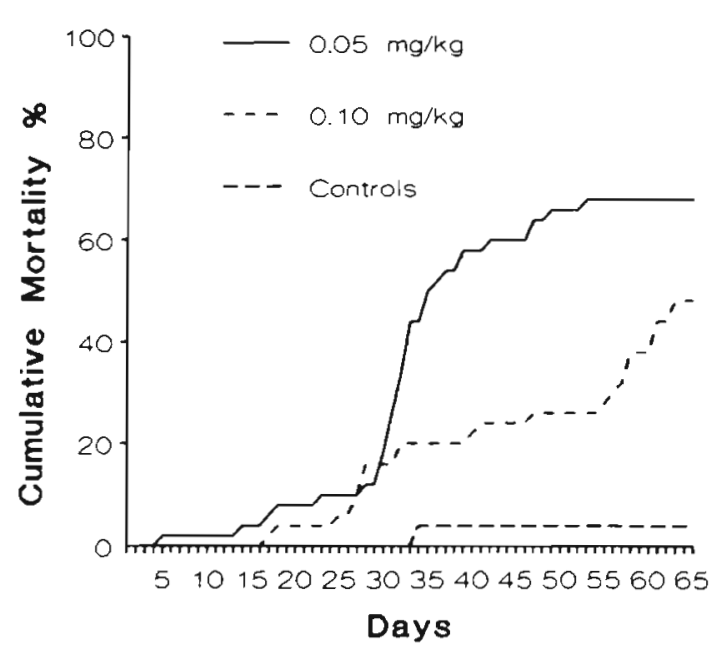

Fig. 4. Oncorhynchus mykiss. Toxicity of orally admınistered ivermectin to steelhead trout. Fish were fed a commercial diet sprayed with ivermectin in the form of a veterinary preparation of $1 \% \mathrm{w} / \mathrm{v}$ oral drench (Eqvalan; Merck Frosst (anada) at targeted dosages of 0.05 and $0.10 \mathrm{mg} \mathrm{kg}^{-1}$ fish every second day. A vibriosis outbreak occurred in all groups 
end of the experiment. In all treatment groups most of the dead fish were heavily infected with Vibrio ordalli. After 8 doses of ivermectin a reduction in feeding activity in both the 0.05 and $0.10 \mathrm{mg} \mathrm{kg}^{-1}$ treatment groups was noted. On average the 0.05 and $0.10 \mathrm{mg}$ $\mathrm{kg}^{-1}$ treatment groups consumed 74 and $57 \%$ of their full treated feed ration, respectively, after this time.

\section{Gross pathology and histology}

Gross examination of moribund Atlantic salmon in the 0.50 and $1.0 \mathrm{mg} \mathrm{kg}^{-1}$ fish treatment groups revealed some congestion of their intestines. Many of the moribund steelhead salmon had enlarged spleens and ascites fluid in their body cavities. Such gross pathology is commonly associated with vibriosis outbreaks. Examination of histological sections of gill, heart, intestine, kidney, liver, pyloric caeca, and spleen revealed no pathological changes that could be associated with ivermectin toxicity in any species

\section{DISCUSSION}

There are few data available on the toxicity of orally administered ivermectin to fish. Over the first $2 \mathrm{~d}$ of this study, single doses of ivermectin at $0.2,0.5$, and $1.0 \mathrm{mg} \mathrm{kg}^{-1}$ administered to Atlantic salmon caused 0 , 8 , and $38 \%$ cumulative mortality, respectively. Smith et al. (1993) reported $26 \%$ mortality of Atlantic salmon given a single oral dose of $0.75 \mathrm{mg} \mathrm{kg}{ }^{-1}$. Palmer et al (1987) reported that a single oral dose of $0.2 \mathrm{mg} \mathrm{kg}^{-1}$ administered over $24 \mathrm{~h}$ did not appear to be toxic to either Atlantic salmon (12.5 to $85 \mathrm{~g}$ average weight) or rainbow trout ( $36 \mathrm{~g}$ average weight). O'Halloran et al. (1992) reported a slight elevation in mortality (0.6\%) and lethargy in Atlantic salmon smolts (35 g average weight) fed a single dose of $0.20 \mathrm{mg}$ ivermectin $\mathrm{kg}^{-1}$ fish. They also reported that mortality rates were elevated (10 to $24 \%$ cumulative mortality) in Atlantic salmon (151 to $221 \mathrm{~g}$ average weight) fed a single dose of $0.4 \mathrm{mg}$ ivermectin $\mathrm{kg}^{-1}$ fish. Rainbow trout (36 $\mathrm{g}$ average weight) fed a single dose of $1.0 \mathrm{mg}$ ivermectin $\mathrm{kg}^{-1}$ had a $38 \%$ cumulative mortality (O'Halloran et al. 1992).

Ivermectin, when used for the control of sea lice, is normally fed at $0.05 \mathrm{mg} \mathrm{kg}^{-1}$ fish every third day (Jackson \& Costello 1992). In our study, ivermectin was fed at this level every second day and resulted in a low cumulative mortality $(10 \%)$ in Atlantic salmon, and no mortality in chinook or coho salmon. Smith et al. (1992, 1993) reported that oral treatments with ivermectin of $0.2 \mathrm{mg} \mathrm{kg}^{-1}$ every $2 \mathrm{wk}, 0.075 \mathrm{mg} \mathrm{kg}^{-1}$ twice a week, $0.1 \mathrm{mg} \mathrm{kg}^{-1}$ once a week, and $0.05 \mathrm{mg} \mathrm{kg}^{-1}$ twice a week administered over long periods of time (9 to $42 \mathrm{wk}$ ) caused no treatment-associated mortalities, no detectable chronic toxicity, and no adverse effects on weight gain.

Results of our experiments indicate that salmon species differ in their ability to tolerate orally administered ivermectin, with coho salmon being the most tolerant followed by chinook and then Atlantic salmon. The reason for this difference remains to be determined. It is possible that these species may differ in their efficiency of ivermectin uptake across the intestine. The results for steelhead trout are difficult to interpret because they were complicated by the development of vibriosis in the experimental groups. Vibriosis was most likely responsible for the high levels of mortality seen in the control and both treatment groups.

Assayed levels of ivermectin in the medicated feeds were generally considerably lower than the targeted levels. Uneven spraying of the feed or lass of ivermectin during frozen storage are possible reasons for these discrepancies. The use of other formulations of ivermectin or methods of incorporation into feeds might influence the level of ivermectin obtained in the feeds and/or its bioavailability. Such changes could have important effects with respect to the toxicity of ivermectin to salmonids.

In our study no pathological changes were associated with ivermectin toxicity. Palmer et al. (1987) also reported no pathological changes in the organs of seawater salmon and freshwater rainbow trout that survived treatment with ivermectin.

Acknowledgements. We thank. Dr T Evelyn for critically reviewing this manuscript and $\mathrm{Mr} \mathrm{C}$. Salisbury of the Health of Animals Laboratory, Agriculture Canada, Saskatoon, for the analysis of ivermectin in the treated feeds. This research was funded by the Department of Fisheries and Ocean's Biological Sciences Branch, Pacific Region. S.C.J. was supported by a Natural Sciences and Engineering Research Council of Canada Postdoctoral Fellowship.

\section{LITERATURE CITED}

Brandal, P. O., Egidius, E. (1979). Treatment of salmon lice (Lepeophtheirus salmonis Kroyer, 1838) with Neguvon ${ }^{R}-$ description of method and equipment. Aquaculture, 18: $183-188$

Campbell, W. C. (ed.) (1989). Ivermectin and abamectin. Springer-Verlag, New York

Doherty, S. J., Fox, A., Fink, D. W. (1990). Determination of ivermectin in medicated swine feeds at the $2 \mathrm{ppm}$ concentration level. J. Ass. off. analyt. Chem. 73: 931-934

Grave, K. Engelstad, M., Soli, N. E. (1991a). Utilization of dichlorvos and trichlorfon in salmonid farming in Norway during 1981-1988. Acta vet. scand. 32: 1-7

Grave, K., Engelstad, M., Soli, N. E., Toverud, E.-L. (1991b). Clinical use of dichlorvos (Nuvan) and trichlorfon (Neguvon) in the treatment of the salmon louse, 
Lepeophtheirus salmonis. Compliance with the recommended treatment procedures. Acta. vet. scand. 32: 9-14

Hogans, W. E., Trudeau, D. J. (1989a). Caligus elongatus (Copepoda: Caligoida) from Atlantic salmon (Salmo salar) cultured in marine waters of the Lower Bay of Fundy. Can. J. Zool. 67: 1080-1082

Hogans, W. E., Trudeau, D. J. (1989b). Preliminary studies on the biology of sea lice, Caligus elongatus, Caligus curtus and Lepeophtheirus salmonis (Copepoda: Caligoida) parasitic on cage-cultured salmonids in the Lower Bay of Fundy. Can. Tech. Rep. Fish. Aquat. Sci. 1715: 14 pp.

Jackson, D., Costello, M. J. (1992). Dichlorvos and alternative sealice treatments. In: De Pauw, N. Joyce, J. (eds.) Aquaculture and the environment. 1991 Spec. Publ. Eur. Aquacult. Soc. 16: 215-221

Jones, M. W., Sommerville, C., Wootten, R. (1992). Reduced sensitivity of the salmon louse, Lepeophtheirus salmonis, to the organophosphate dichlorvos. J. Fish Dis. 15: $197-202$

Kabata, Z. (1979). Parasitic Copepoda of British fishes. The Ray Society, London

Kabata, Z. (1988). Copepoda and Branchiura. In: Margolis, L., Kabata, Z. (eds.) Guide to the parasites of fishes of Canada. Part II. Crustacea. Can. Spec. Publ. Fish. Aquat Sci. 101: 3-127

O'Halloran, J., Ogden, C. D., Hogans, W. E. (1992). Ergasilus labracis on Atlantic salmon. Can. vet. J. 33: 75

Palmer, R., Rodger, H., Drinan, E., Dwyer, C., Smith, P. R. (1.987). Preliminary trials on the efficacy of ivermectin

Responsible Subject Editor W. Körting, Hannover, Germany against parasitic copepods of Atlantic salmon. Bull. Eur Ass. Fish Pathol. 7: 47-54

Pike, A. W. (1989). Sea lice - major pathogens of farmed Atlantic salmon. Parasitol. Today 5: 291-29?

Reyes, P. X., Bravo, S. S. (1983). Note on the presence of parasitic copepods on cultured salmons. Invest. mar. Univ. Catol. Valparaiso 11.55-57

Roth, M., Richards, R. H., Sommerville, C. (1993). Current practices in the chemotherapeutic control of sea lice infestations in aquaculture. J. Fish Dis. 16: 1-26

Smith, P., Moloney, M., McElligott, A., Clarke, S., O'Brien, F. (1992). Studies of the efficacy of orally administered ivermectin as a method for the control of sea lice infestations of farmed Atlantic salmon. First European Crustacean Conference Abstracts, Paris, France. Aug. 31-Sept. 5, 1992., p. 149

Smith, P. R., Moloney, M., McElligott, A., Clarke, S., Palmer, R., O'Kelly, J., O'Brien, F. (1993). The efficiency of oral ivermectin in the control of sea lice infestation of farmed Atlantic salmon. In: Boxshall, G. A., DeFaye, D. (eds.) Pathogens of wild and farmed fish: sea lice. Ellis Horwood, Chichester, p. 296-307

Sokal, R. R., Rohlf, F. J. (1981). Biometry. W. H. Freeman and Company, New York

Wootten, R., Smith, J. W., Needham, E. A. (1982). Aspects of the biology of the parasitic copepods Lepeophtheirus salmonis and Caligus elongatus on farmed salmonids, and their treatment. Proc. R. Soc. Edinb. (Sect. B.) 81: $185-197$

Manuscript first received: April 1, 1993

Revised version accepted: June 6, 1993 